\title{
Effect of Earnings Announcement on Share Prices of Companies Listed at the Nairobi Securities Exchange
}

\author{
Olang Margaret Akinyi, Akenga Grace Melissa \\ Faculty of Business Studies, Chuka University, Chuka, Kenya \\ Email address: \\ margaretolang087@gmail.com (O. M. Akinyi), akengamgrace@gmail.com (A. G. Melissa)
}

\section{To cite this article:}

Olang Margaret Akinyi, Akenga Grace Melissa. Effect of Earnings Announcement on Share Prices of Companies Listed at the Nairobi Securities Exchange. European Business \& Management. Vol. 3, No. 2, 2017, pp. 29-36. doi: 10.11648/j.ebm.20170302.13

Received: February 13, 2017; Accepted: February 27, 2017; Published: March 24, 2017

\begin{abstract}
Limited companies are characterized by separation of management and ownership, at the end of each financial period managers have a duty to communicate to the shareholders on the financial performance of the firm which is usually done through earnings announcement. Managers strive to maximize shareholders wealth by making rational financial decisions. Earnings announcements are important since it determines the firm's financial performance in terms of profits and wealth. The inefficiencies in our markets today raise an issue on whether investors should cash in on the inefficiencies or encourage professionalism. Through market research investors can move from observing trends to a solid and more grounded investing that has an inclination to long term positive gains. The objectives of the study were; to determine how efficiently share prices react to earnings announcements, and the influence of the content of earnings announcements to investment decisions made by investors. The target population was all the 61 companies listed at the Nairobi securities exchange (NSE). Purposive sampling technique was used to select 8 companies as a sample size. The event study methodology was used to determine the effect of earnings announcement on share prices. Data was analyzed descriptively using mean and standard deviation while inferences were made using correlation analysis and t- statistic. The results obtained indicate that the abnormal returns around the earnings announcements date were not significant at 5\% level. The study found negative relationship between the content of earnings announcements of firms listed at the NSE. There was also a significant difference between earnings announcement and share price changes. The study found that shares have positive returns before earnings announcement and negative returns in months immediately following the announcement. This study also established that all stocks studied have a positive beta value indicating that they adjust linearly to the performance of the market index. Five of them have a beta above one meaning that their systematic risk or return volatility is greater than the stock market. Increased volatility means more risk to the investors and there are higher abnormal returns for stocks which have a beta greater than one. The study provides information to investors to help them analyze the earnings in order to determine the firm's profitability and wealth.
\end{abstract}

Keywords: Earnings Announcement, Share Price, Market Efficiency, Shareholders Wealth, Event, Announcement Day

\section{Introduction}

Earning announcement information plays a very important role in the functioning of stock markets at both individual and institutional investor levels Stock market reaction to earnings announcement has received significant attention in Finance and Accounting literature. Ball and Brown (1968), and Aharony and Swary (1980) are some of the studies that observe a revision of stock prices associated with the release of earnings announcements. When firms release their earnings, analysts compare them to their predetermined estimates for the quarter of the financial year concerned. The estimates are based on the firm's past performance, recent good or bad news about the firm, and any outside effects (that is, economic conditions), that may affect the firm's performance. Earnings reports which are higher or lower than analysts' comprise earnings surprises.

Surprise earning announcements can significantly affect stock prices. Positive surprise earnings announcements typically drive up the firm's stock price by sending a positive signal to investors about the firm's future cash flows. Conversely, a negative earnings surprise announcement exerts a downward pressure on stock prices as investors 
perceive a negative signal about the firm's future. For over 40 years, researchers have consistently documented the phenomena in stock markets where stock prices tend to drift in the direction of the earning surprise following earning announcements. This phenomenon is referred to as the Post Earnings Announcement Drift (PEAD). A vast body of research has documented the tendency of stock prices to show a continuous drift after the release of earning announcements. The systematic increase in price returns around earnings announcements can be observed in periods either before or after earning announcements.

How fast the stock market reacts to publicly announced information will depend on how efficient the stock market is. Market efficiency refers to a condition in which current prices reflect all the public available information about a security. The basic idea underlying market efficiency is that competition will drive all information into the price quickly. An efficient market arises or emerges when new information is quickly incorporated into the share prices. In other words, the current market price of a security reflects all available information in an efficient market.

The growth of businesses in Africa will depend on the ability of these businesses to expand and have a greater market share not only in the region but also beyond the continent's boundaries. This means businesses will have to raise additional borrowings in order to expand. Basically, the size of retained earnings of a business depends largely on what is paid out to shareholders or the dividend policy of the business. Considering the fact that gearing usually has negative implications on the image of a business and retained earnings are difficult to come by, the probable solution is through the stock market (Osei, 1996).

An efficient market should therefore portray equality in pricing of shares. With available information, the market makes expectations of the prospects of the share and therefore gives an accurate intrinsic value of the security. Should the price differ from the expected value, buying and selling will take place and this will subsequently cause the market price to rise or fall until the value placed on the share by the market is reached. This means that under efficient markets, share price is a good estimate of the value placed on the security by the market at any point in time and hence abnormal volatility resulting to abnormal gains cannot be witnessed. Unfortunately, this is not the case in emerging and frontier capital markets, such as the Kenyan Stock Market. According to a study done by Osei (1996) a sizeable number of Ghanaian investors do not know much about the operation and mechanisms of the capital markets. Therefore, the ability of the frontier market to impound financial information and incorporate it into prices to match the risk is in doubt. The lack of understanding and the poor state of communication to facilitate information flow has been blamed. They are required to do, considerable price volatility and increases in trading volume are evident. The inefficiencies in our markets today raise an issue on whether investors should cash in on the inefficiencies or encourage professionalism and thorough market research that will move investors from trends to a solid and more grounded investing that has an inclination to long term positive gains. Therefore there was need to establish the effect of earnings announcements on share price changes for companies listed at the NSE.

\section{Review of Literature}

\subsection{Theoretical Framework}

Arbitrage Pricing Theory is a theory of asset pricing that holds that the expected return of a financial asset can be modeled as a linear function of various macro-economic factors or theoretical market indices, where sensitivity to changes in each factor is represented by a factor-specific beta coefficient. The model-derived rate of return will then be used to price the asset correctly - the asset price should equal the expected end of period price discounted at the rate implied by the model. If the price diverges, arbitrage should bring it back into line. It describes the price where a mispriced asset is expected to be.

Fama (1970) defines efficient market theory as an investment theory that states it is impossible to "beat the market" because stock market_efficiency causes existing share prices to always incorporate and reflect all relevant information. According to the EMH, stocks always trade at their fair value on stock exchanges, making it impossible for investors to either purchase undervalued stocks or sell stocks for inflated prices. As such, it should be impossible to outperform the overall market through expert stock selection or market timing, and that the only way an investor can possibly obtain higher returns is by purchasing riskier investments.

According to Fama (1970) an efficient market has a large number of rational profit maximisers who are actively competing with each other trying to predict future market values of individual securities, and where important current information is almost freely available to all participants. This competition among the participants leads to a situation where, at any one point in time, actual prices of individual securities already reflect the effects of information, based both on events that have already occurred and on events which as of now, the market expects to take places in the future. In other words, in an efficient market at any point in time the actual price of a security will be a good estimate of its intrinsic value.

Market efficiency can be tested on three levels of information; information on past prices, all publicly available information, and all public and private information. Weak form efficiency hypothesizes that stock prices reflect all the information found in past stock prices. If the market is weak form efficient, then stock prices react so fast to past information that no investor can earn an above normal riskadjusted return by acting on this level of information. The semi-strong form asserts that all publicly available information is fully reflected in security prices. Included in this information are published financial statements and any historical information. When a market is semi-strong 
efficient, stock prices should reflect all information released making it impossible to earn above normal return by acting on publicly available information. Strong form efficiency hypothesizes that stock prices immediately incorporate all information, both public and private. Private information relates to insider corporate information which is only known to the management of the company. This may include such issues like changes in management, introduction of new accounting techniques and so on.

Rationality theory argues that all investors are rational thus when new information is released to the market they adjust their estimates of stock prices in a rational manner. The share prices rise immediately when good information is released because the investors see no reason to wait before trading at the new prices. The major shortcoming of this model is that not all investors are rational (Bodie, Kane\& Marcus, 2008)

\subsection{Event Studies}

To test for the effects of new information on stock prices, researchers use an approach called an event study.

\subsubsection{Weak-Form}

Fama (1970) summarized the early efficient market literature using his own contributions and other studies of the information contained in the historical sequence of prices, and concluded that the results were strongly in support of the weak form of market efficiency. He then reviewed a number of semistrong and strong form tests, and concluded that, "in short, the evidence in support of the efficient markets model is extensive, and contradictory evidence is sparse". He however conceded that much remained to be done and he indeed returned to the field in 1991 with a re-interpretation of the efficient markets hypothesis in the light of subsequent research.

Another study, 'Weak Form Efficiency and Mean Reversion in the Malaysian Stock Market' was conducted by Kok Kim Lian and Goh Kim Leng, addressing the issue of weak form market efficiency in the Malaysian case by examining the random walk behavior of stock prices over the short run in the Kuala Lumpur Stock Exchange (KLSE). This study used the closing levels of the seven KLSE stock indices; Composite Index, Emas Index, and the five Sectoral Indices. The tests employed were run tests, serial correlation test, Ljung-Box-Pierce Q test, and the Von Neumann's ratio test, which are based on returns of short horizons. Kok and Goh used the daily, weekly, and monthly levels of the seven KLSE stock indices over a period of 9 years (1984-1992). Mean while, results were given for the two equal sub-periods of 1984-June 1988, and July 1988-1992 in order to make comparisons. Study on the long-run random walk behavior in the KLSE was also given attention by Kok and Goh as the phenomena of short-run random walk behavior might not hold in the long-run. This was because they could revert to some mean level over longer horizons and they would thereby be said to be mean reverting. The study was done by investigating whether indices exhibited mean reversion. In the run test to confirm the efficiency which compared the actual number of runs with the expected in order to determine the dependence in price changes, no conclusion was made by Kok and Goh since the results were in contrast among the daily, weekly, and monthly data. The results of the various statistical tests on the KLSE daily stock indices indicated serial dependence and successive price changes. All the tests showed that the Malaysian Stock Market had improved its efficiency from a weak form inefficient market in the mid 1980 's to a weak form efficient market by the late 1980's and early 1990's.

\subsubsection{Semi-Strong Form}

Studies of the semi strong form of the efficient market hypothesis can be categorized as test of the speed of adjustment of prices to new information. The principal research tool in this area is the event study. An event study averages the cumulative performance of stocks over time, from a specified number of time periods before an event to a specified number of periods after. Performance for each stock is measured after adjusting for market-wide movements in security prices.

The first event study was undertaken by Fama, Fisher, Jensen, and Roll (1969), though the first to be published was by Ball and Brown (1968). Using the market model or Capital Asset Pricing Model (CAPM) as a benchmark, these event studies provide evidence on the reaction of share price to stock splits or earning announcements. In both cases, the market appears to anticipate the information, and most of the price adjustment is complete before the event is revealed to the market. When news is released, the remaining price adjustment takes place rapidly and accurately. The Fama, Fisher, Jensen, and Roll's study, in particular, demonstrates that prices reflect not only direct estimates of prospective information by the sample companies, but also information that requires more subtle interpretation.

\subsubsection{Strong Form}

Since the first event studies, numerous papers have demonstrated that early identification of new information can provide substantial profits. Insiders who trade on the basis of privileged information can therefore make excess returns, violating the strong form of the efficient market hypothesis.

The first such study was Treynor's (1965) article in the Harvard Business Review on the performance of mutual funds. The most frequently cited article on fund managers' performance was to be the detailed analysis of 115 mutual funds over the period of 1955-64 undertaken by Jensen (1968). On a risk-adjusted basis, he finds that any advantage that the portfolio manager might have is consumed by fees and expense. Fama (1998) summarizes a number of subsequent studies of mutual funds and institutional portfolio managers' performance. Though some mutual funds have achieved minor abnormal gross returns over expenses, pension funds have underperformed passive benchmarks on a risk-adjusted basis.

\subsection{Information Content of Earning Announcements}

According to Ball and Brown (1968), prices anticipate 
earnings surprises. Thus, some information signals, possibly including informed trades, are realized before earnings announcements and convey information to the market regarding the announcement. Trades by corporate insiders are an example of informed trade that anticipates future disclosures. For example, Mandelker et al (1992) reports that almost half of the price run-up before takeovers occurs on days when insiders trade on knowledge of the takeover, suggesting that ' the stock market detects informed trading and impounds large proportion of the information into the stock price before it becomes public.' Past event studies done tried to answer whether an event (that is, earning announcement) convey new information to make market participants as reflected in changes in the level or variability of security prices or trading volume over a short period of time surrounding the event.

Association studies done on the other hand test for positive correlation between accounting performance measures (for example earning or cash flows from operations) and stock returns, both measured over relatively long time periods, for instance one year. However, these studies do not assume that financial reports are the only source of information and no causal connection is inferred. The studies proved that earnings surprises correlated with stock returns. Beaver (1968) suggested that return volatility and trading volume which is evidence of information flow to the market increases during earnings announcements. Bernard and Thomas $(1980,1990)$ proved in their studies that market response to earnings is asymmetric (that is, good news gets incorporated into price faster than bad news).

\subsection{Earnings-Returns Responsiveness}

Earnings Response Coefficient (ERC) is the coefficient from a regression of returns on earnings. It represents a mapping of earnings' time-series properties and discount rates into changes in equity values. Also, it represents the present values of the revisions of expected future earnings. Prior literature has identified four determinants of ERC; persistence $(+)$, growth $(+)$, beta $(-)$, and interest rates $(-)$; which relate ERC to economic determinants such as competition, technology, innovation, effectiveness of corporate governance compensation, and so on. Kormendi and Lipe (1987) show that earnings surprises cause investors and analysts to revise their expectations about future earning levels. Other studies determined that the sign and magnitude of stock prices responses are correlated positively with the sign and magnitude of unexpected earnings (Ball and Brown, 1968; Beaver, 1968).

\subsection{Earnings Quality and Other Signals}

Earnings quality is an important aspect of evaluating an entity's financial health. According to Durfee (2004), it refers to the ability of reported earnings to reflect the company's true earnings, as well as the usefulness of reported earnings in predicting future earnings. It also refers to the stability, persistence, and lack of variability in reported earnings. The evaluation of earnings is often difficult because companies highlight a variety of earnings figures: revenues, operating earnings, net income, and proforma earnings. In addition, companies often calculate these figures differently. Pratt (2006) defines earnings quality as the extent to which net income reported on the income statement differs from true earnings. Hodge (2006) suggested that an investor's perception of Earnings Quality depends on auditor independence, and the usefulness of audited financial information. According to Penman (2003), the quality of earnings is based on the quality of forward or future earnings as well as current reported earnings.

\subsection{Earnings Announcements}

The amount of profit that a company produces during a specific period, which is usually defined as a quarter (three calendar months) or a year. Earnings typically refer to aftertax net income. Ultimately, a business's earnings are the main determinant of its share price, because earnings and the circumstances relating to them can indicate whether the business will be profitable and successful in the run. Companies operate with the aim of making profit and hence increasing the shareholders wealth. At the end of every financial year, financial reports that communicate the firms' performance are prepared and availed to all stockholders. In Kenya it is mandatory to publish for all listed companies to publish the annual and semi annual reports in at least two English daily newspaper and copies of the report availed to the capital market authority.

\section{Methodology}

Causal research design was used because it attempts to determine the cause effect relationship between the independent variables and dependent variable. According to Copper and Schindler (2006) this design was used to explain how the independent variables produce change in the dependent variable therefore determining the cause effect relationship that exists among variables. Purposive sampling was used to select a sample size of 8 companies. Specifically it involved sampling the daily closing stock prices of publicly listed companies that made annual announcements from 2010 to 2015, 60 days before and after announcement. The sample for the entire study was arrived by determining all the companies that made annual earnings announcement during the period under study and has been listed and actively trading throughout the study period. Secondary data was extracted from the audited annual reports and financial statements of individual companies sourced from the NSE and the Capital Market Authority. Data was analysed using descriptive and inferential statistics. The standard event study methodology was based on the assumption that it is possible to isolate the part of a stock's return which concerns a particular event. The particular event in this study was the earnings announcement surrounding stocks or shares of companies listed at the Nairobi Stock Exchange. This was done by using a model to estimate the normal return, which is 
the stock's return if the event (earning announcement) had not happened. The abnormal return which the event generates was found as the difference between the actual return and the estimated normal return. The information content of an event was then examined by evaluating the abnormal returns around the announcement date. The test therefore provided an investigation of the relationship between the return earned by a particular stock compared with the return earned by the market as a whole.

For this particular study the standard market model, which assumes a linear relationship between the return of a given security to the return of the market portfolio is used. By using the least square regression analysis, the return on an individual stock or security may be represented through the following model;

$$
R i t=\alpha+\beta R m t+\mu
$$

Where;

Rit represents the return on asset $i$ in period $t$

$R m t$ represents the return on the market index in period $t$

$\alpha$ represents a constant in regression equation

$\beta$ represents the volatility of the asset return relative to the market index (that is, the beta value of asset $i$ )

$\mu$ represents the disturbance or error term of the regression equation

This can be diagrammatically represented as follows;

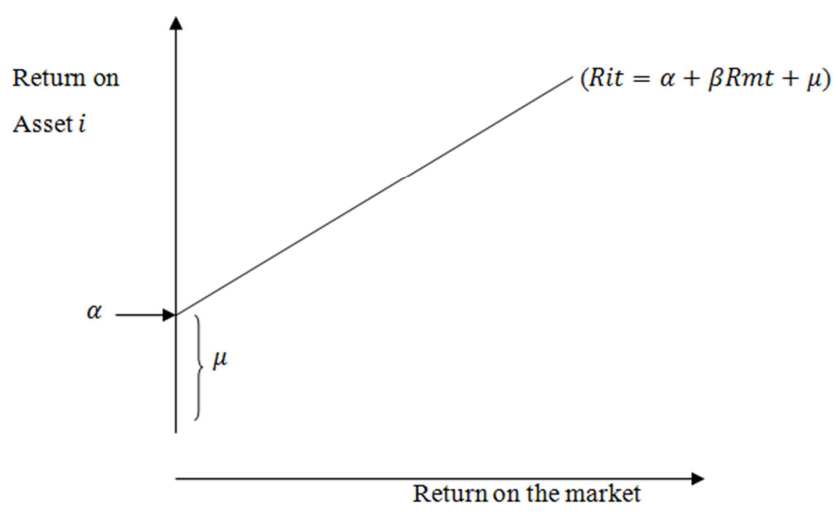

Figure 1. Linear Regression between Asset $i$ and the Market.

\section{Results and Discussions}

\subsection{Reaction of Share Prices to Earnings Announcements}

In order to test the reaction of share prices to earnings announcements, the study used average share prices of the month before announcement, average share prices of the month of announcement, average share prices 1 month after announcement, and also share prices 2 month after announcements.

Table 1. Relationship between Average Share Prices before Announcements and Average Share Prices one Month after Announcement.

\begin{tabular}{llll}
\hline Announcement & Mean & Standard deviation & Sig \\
\hline $\begin{array}{l}\text { Prices before announcement } \\
\begin{array}{l}\text { Prices after first month } \\
\text { announcement }\end{array}\end{array}$ & 46.44 & 44.050 & 0.635 \\
\hline
\end{tabular}

According to table 1 , there is no significant difference in the means of share prices before the announcement and one month after the announcement. The calculated $t$-value is 0.171 , the p-value is 0.896 , and df is 7 .

Table 2. Relationship between Average Share Prices before Announcements and two Months after Announcements.

\begin{tabular}{lllll}
\hline Announcement & Mean & N & Std. Deviation & Sig \\
\hline $\begin{array}{l}\text { Prices before } \\
\text { Announcement }\end{array}$ & 46.44 & 8 & 44.050 & 0.532 \\
$\begin{array}{l}\text { Prices after 2nd Month } \\
\text { Announcement }\end{array}$ & 45.19 & 8 & 45.507 & 0.676 \\
\hline
\end{tabular}

Table 2 shows that there is no significant difference in the means of share prices before announcements and two months after announcement with a calculated t-value of 0.436 , pvalue of 0.676 , and a df of 7 .

Table 3. Relationship between Average Share Prices in Month of Announcement and One Month after Announcement.

\begin{tabular}{lllll}
\hline Announcement & Mean & N & Std. Deviation & Sig \\
\hline $\begin{array}{l}\text { Prices during Announcement } \\
\text { Prices after 1st Month }\end{array}$ & 56.25 & 8 & 51.394 & 0.02 \\
Announcement & 46.84 & 8 & 43.787 & 0.013 \\
\hline
\end{tabular}

This table shows a significant difference in the means of share prices in the month of announcements and one month after announcement with a calculated t-value of 3.333 , a pvalue of 0.013 , and a df of 7 .

Table 4. Relationship between Average Share Prices in Month of Announcement and two Months after Announcement.

\begin{tabular}{lllll}
\hline Announcement & Mean & N & Std. Deviation & Sig \\
\hline $\begin{array}{l}\text { Prices during Announcement } \\
\text { Prices after 2nd Month }\end{array}$ & 56.25 & 8 & 51.394 & 0.03 \\
Announcement & 45.19 & 8 & 45.507 & 0.042 \\
\hline
\end{tabular}

Table 4 shows a significant difference in the means of share prices in the month of announcements and share prices two months after announcements with a calculated t-value of 2.489 , a p-value of 0.042 , and a df of 7 .

Table 5. Relationship between Average Share Prices in Months of Announcement and Month before Announcement.

\begin{tabular}{lllll}
\hline Announcement & Mean & N & Std. Deviation & Sig \\
\hline Prices before Announcement & 46.44 & 8 & 44.050 & 0.042 \\
Prices during Announcement & 56.25 & 8 & 51.394 & 0.039 \\
\hline
\end{tabular}

This table shows a significant relationship in the means of share prices in the month of announcement and share prices in the month before announcement with a calculated t-value of 2.534, a p-value of 0.039 , and a df of 7 .

Thus, it is evident that earnings announcements have a significant relationship with average share prices in the month before announcements, in the month of announcement, one month after announcement, and also two months after announcement. This overrules the first hypothesis which states that there is no significant relationship between share prices of a company and its earnings announcement. 


\subsection{The Influence of Abnormal Returns to Investment Decisions Made by Investors}

The study also seeks to evaluate whether the abnormal returns arising from earnings announcements have a significant influence on the investment decision that investors make. Abnormal returns are calculated as the difference between the predicted return and the actual return on a stock, where the predicted return is calculated using the model:

$$
R i t=\alpha+\beta R m t+\mu
$$

Table 6. Regression Result of NSE Companies.

\begin{tabular}{lll}
\hline Company & $\boldsymbol{\alpha i}$ & $\boldsymbol{\beta} \boldsymbol{i}$ (Systematic risk) \\
\hline City Trust Ltd & 2.1313 & 0.93 \\
Kakuzi Ltd & 1.2280 & 0.82 \\
CMC Ltd & 0.9500 & 1.14 \\
Barclays Bank & 0.3581 & 1.43 \\
Nation Media & 4.9991 & 1.71 \\
Centum Inv. & 1.0368 & 1.41 \\
Mumias Sugar & 1.8551 & 0.97 \\
Sameer Africa & 0.2194 & 1.52 \\
\hline
\end{tabular}

From the regression Table 6, all eight stocks have a positive beta value. The beta value in this case is useful in giving insight of the reaction of a stock to the market performance in particular the market index. CMC Holdings, Barclays Bank of Kenya, Nation Media Group, Centum Investment, and Sameer Africa have betas greater than one, meaning that the systematic risk or return volatility of the stocks are greater than the market beta of one. Therefore share prices of these stocks experience movements that are greater than the stock market. Since increased volatility of share price means more risk to the investor, it is expected that there will be abnormal return from stocks with betas over one. City Trust, Kakuzi, and Mumias have a beta less than one. This means that the volatility of these stocks is less than that of the market and hence lower abnormal returns.

The alpha values $(\alpha)$ of the stocks indicate their riskadjusted return or the actual return in relation to the expected return based on their various beta values. A larger alpha value is preferred by investors. Since it will generate excess returns over a given time period, they view it as a good incentive. From table 6 Nation Media Group has the highest alpha value as compared to the other stocks. This indicates higher expected returns. On the other hand, Sameer Africa has the lowest alpha value indicating that the expected return is much lower as compared to the rest of the companies.

\subsection{Correlation}

Correlation Coefficient was used to determine the strength and nature of linear relationship among the variables. The value of coefficient of correlation lies between -1 to +1 representing perfectly negative and perfectly positive correlation respectively.

\subsubsection{Correlation Co-efficient Relationship Between Abnormal Returns and Earnings Per Share (EPS)}

The computed correlation co-efficient is 0.288 and a pvalue of 0.172 . This implies that there is no significant statistical relationship between abnormal returns and earnings per share. The relationship is weak and positive although not significant. This means that, the higher the abnormal returns, the higher the earnings per share. However, this relationship is not significant.

\subsubsection{Correlation Co-efficient Relationship Between Abnormal Returns and Earnings Announcements in Millions}

The computed correlation co-efficient is 0.36 and a p-value of 0.357 . This implies that there is no significant statistical relationship between abnormal returns and earnings per share. The relationship is weak and positive although not significant. This means that, the higher the abnormal returns, the higher the earnings announcements in millions. However, this relationship is not significant.

\subsubsection{Dependence of Abnormal Returns to Earnings Announcements and Earnings Per Share}

A linear regression is used to test whether abnormal returns depend on earnings announcements and earnings per share. The model used was,

\section{Abnormal Return $=\beta 0+\beta 1$ Earnings announcements + $\beta 2 E P S+$ Error term}

The results are as follows

Table 7. Regression Analysis

\begin{tabular}{lll}
\hline Parameter & Estimates & P-value \\
\hline$\beta 0$ & -5480.125 & 0.00 \\
$\beta 1$ & 0.888 & 0.355 \\
$\beta 2$ & 112.10 & 0.175 \\
\hline
\end{tabular}

$\beta 1$ which is an estimate for earnings announcements in millions is positive showing that the relationship between earnings and abnormal return is positive. $\beta 2$ which is an estimate for earnings per share is positive showing that the relationship between earnings per share and abnormal returns is positive. The $p$ value of 0.355 and 0.175 shows that the independent variables, earnings announcements and earnings per share do not significantly affect the abnormal returns.

Table 8. Goodness of Fit.

\begin{tabular}{lll}
\hline $\mathbf{R}$ & R Square & Adjusted $\mathbf{R}^{\mathbf{2}}$ \\
\hline 0.192 & 0.037 & 0.031 \\
\hline
\end{tabular}

Table 8 is the model summary with the value of R2 as 0.037 implying that about $3.7 \%$ of variation can be explained by the independent variable and $96.3 \%$ can be accounted for by other factors that are not within the control of the researcher. The regression results indicate that the independent variables are not significant in affecting the dependent variable. 
Table 9. Anova.

\begin{tabular}{llllll}
\hline & Sum of Squares & df & Mean Square & F & Sig. \\
\hline Regression & 9175825.517 & 2 & 4587912.758 & 1.440 & .259 \\
Residual & 66891841.360 & 21 & 3185325.779 & & \\
Total & 76067666.876 & 23 & & & \\
\hline
\end{tabular}

Table 9 shows that the regression is not statistically significant at 0.05 or $5 \%$ significance level.

These findings support the second hypothesis which states that there is no significant relationship between the content of earnings announcements of listed firms and the investment decisions made by investors.

\section{Conclusions and Recommendations}

The study revealed that share prices respond to earnings announcements in the month of earnings announcement and also during the first and second month after announcements have been made. This was demonstrated by an increase in average share prices in the announcement month as compared to the average share prices in the month before announcements. It was followed by a decrease in average share prices in both the first and second month after announcements showing that the NSE is semi-strong efficient market, since share prices only react to currently available information which in this case is the earnings announcements. The relationship between earnings announcements and abnormal returns is positive. The relationship between earnings per share and abnormal returns is also positive as observed from the study. However, these relationships are weak though positive meaning that there is no significant relationship which can influence the decisions that investors make. From the study of dependence of abnormal returns to earnings announcements and earnings per share, it was clear that earnings announcements are positive showing that the relationship between earnings announcements and abnormal returns is positive. The relationship between earnings per share and abnormal returns was also positive. However with only $3 \%$ dependence level, it was clear that earnings announcements and earnings per share do not significantly affect the abnormal returns. When investing, investors prefer high abnormal returns. From this study, it is clear that there is no significant relationship between earnings announcements, earnings per share, and abnormal returns. It is therefore right to conclude that the content of earnings announcements which include earnings in millions, earnings per share and corresponding abnormal returns have no significant influence on the investment decisions made by investors. Capital Market Authority should strengthen the regulation of listed firms in order to ensure that public confidence is boosted and hence increasing efficiency of the market. Investor protection will help reduce agency problems and information asymmetry. In addition, the promotion of institutional investors should be encouraged at the Kenyan Stock Market. This will help increase the efficiency of the market due to their diligence and focus on research and details.

\section{References}

[1] Aharony, J and Swary, I (1980). Quarterly Dividend and Earning Announcements and Stockholders' Return: An Empirical Analysis. Journal of Finance, March 1980.

[2] Annuar, M. N. and Shamsher, M (1993). The Efficiency of Kuala Lumpur Stock Exchange. Pernerbit Universiti, Pertanian Malaysia.

[3] Atiase, R (1985). Predisclosure Information, Firm Capitalization, and Security Price Behavior around Earnings Announcement. Journal of Accounting Literature Vol 23, pp 21-36.

[4] Ball, R. and Brown, P (1968). An Empirical Evaluation of Accounting Income Numbers. Journal of Accounting Research Vol 6, pp 159-178.

[5] Beaver, W. H (1968). The Information Content of Annual Earnings Announcement. Journal of Accounting Research Vol 6 (3), pp 67-92.

[6] Bernard, V. L. and Thomas, J. K (1990). Evidence that Stock Prices Do Not Fully Reflect the Implication of Current Earnings to the Future Earnings. Journal of Accounting and Economics Vol 13, pp 305-340.

[7] Bodie, Z., Kane, A., \& Marcus, A. (2008). Investments. Singapore: Mc Graw Hill. International.

[8] Chan, W. R et al (2004). Testing Behavioral and Finance Theories using Trends and Sequences in Finance Performance. Journal of Accounting and Economics Vol 38, pp 3-50.

[9] Cornell, B. and Landsman, W. R (1989). Security Price Response to Quarterly Earnings Announcements and Analysts' Forecast Revisions. The Accounting Review Vol LXIV No 4.

[10] Debondt, W. and Thaler, R (1985). Does the Stock Market Over-react. Journal of Finance Vol 40, pp 793-805.

[11] Fama, E. et al (1969). The Adjustment of Stock Prices to New Information. International Economic Review Vol 10, pp 1-21.

[12] Fama, E (1970). Efficient Capital Markets: A Review of Theory and Empirical Work. Journal of Finance Vol 25, pp 383-417.

[13] Fama, E (1978). Foundations of Finance. New York: Basic Books.

[14] Fama, E (1998). Market Efficiency, Long Term Returns, and Behavior Finance. Journal of Financial Economics Sep 1998, pp 283-306.

[15] Jensen, M (1968). The Performance of Mutual Funds in the Period 1945-1964. Journal of Finance Vol 23, pp 389-416.

[16] Kok, K. L. and Goh, K. L (1995). Malaysian Securities Market. Selangor: Pelanduk Publications.

[17] Kormendi, R. and Lipe, R (1987). Earnings Innovation, Earning Persistence, and Stock Returns. Journal of Business Vol 60 (3), pp323-345.

[18] Mandelker, G. N et al (1992). The post-Merger Performance of Acquiring Firms: A Re-examination of an Anomaly. Journal of Finance Vol 47, pp 1605-1621. 
[19] Osei, K. A (1996). Analysis of Factors Affecting the Development of an Emerging Capital Market: The Case of the Ghana Stock Market. AERC Research Paper 76 Nairobi, Kenya.

[20] Pandey, I. M (2004). Financial Management $\left(9^{\text {th }}\right.$ ed). New Delhi: Vikas Publishing House Pvt Ltd.

[21] Ross, S. et al (2005). Corporate Finance $\left(7^{\text {th }}\right.$ ed). US: McGraw-Hill Cos.
[22] Sharpe, W. F (1964). Capital Asset Prices. A Theory of Market Equilibrium under Conditions of Risk. Journal of Finance Vol XLX (3), pp 425-442.

[23] Shleifer, A. and Vishney, R (1996). A Model of Investor Sentiment. CRSP Working Paper 443 Graduate School of Business, University of Chicago.

[24] Watts, R. L. and Zimmerman, J. L (1986). Positive Accounting Theory. Eanglewood Cliffs, New Jersey: Prentice-Hall Inc. 